\title{
Spinal neurosurgeons, be ambitious !!
}

藤枝だより

本誌の巻頭言には，いずれの先生方も格調の高い随筆 を寄稿して扔られますが，私は思いつくままに幾つかの 事につき書き記します。

20 年来勤務した自治体病院に別れを告げ，当地に参り まして 9 ヶ月目となりました。脊䯑春椎疾患治療センタ 一の旗は掲げましたが，まだ内実はともなっておらず， これから徐々に整備して行く予定です，現在は，近畿大 学から中西欣弥先生, 千葉大学加田宮亜堂先生が研修 中で, 行く行くはそれぞれの大学で立派な脊䯣グループ を立ち上げてくれることと楽しみにしております。両先 生以外に, 以前からこちらの病院に在籍していた吉田 守先生, 井水秀栄先生がセンターの業務を手伝ってくれ ており, 計 4 名半で運営しています。まだ外来も病棟も 血管障害・脳腫痬などの患者と混合した状態での運営で すが，数年のうちに完全に独立した形態にしたいと考え ています。現在発足以来脊髄脊椎手術は200件を越えま したので, 初年度としては300件程度の手術かと思いま す. 数年のうちには500-600件程度の施設にしたいと考 えています. 当地の虎の穴で生活してみたい方が扔られ ましたならば歓迎いたしますので，ご連絡下さい。

北大の岩崎喜信先生の多大なご苦労により本年度脊髄 外科指導医制度が発足しました，数年のうちには認定医 制度も開始されるものと思います. 残念なことに, わが 国の整形外科医たちによる別個の専門医制度も立ち上が っています。整形外科と脳神経外科の共通の領域として の脊䯣脊椎外科に扔いて，両者にまたがるような専門医 制度の誕生を願っていた私としては，非常に残念なこと です。この二つの制度は今後少なくとも10年間ぐらいは それぞれ独自の道を歩むことになろうかと思いますが， このような状況になったからには，私たち脳神経外科医 は，あらゆる面で今まで以上の研鑚が必要であろうと思 います。

以前から繰り返し話してきましたが, 脊䯣脊椎外科に おける脳神経外科医のレーゾン・デートルとは一体何で あるかをこの際もう一度考えてみることが必要と思いま す。ある脳神経外科医は「われわれはマイクロサージャ リーを行っている．かれらの手術は血だらけで見てはお れない」と言います。しかしながら，わが国の整形外科 医も40歳台より若手になると既にマイクロ下の手術に熟 練しつつあり，この技術のある無しで彼らと私たちを区 別することは無意味なこととなる日はそう遠くないと思 われます。この点は十分に心しておく必要があります。

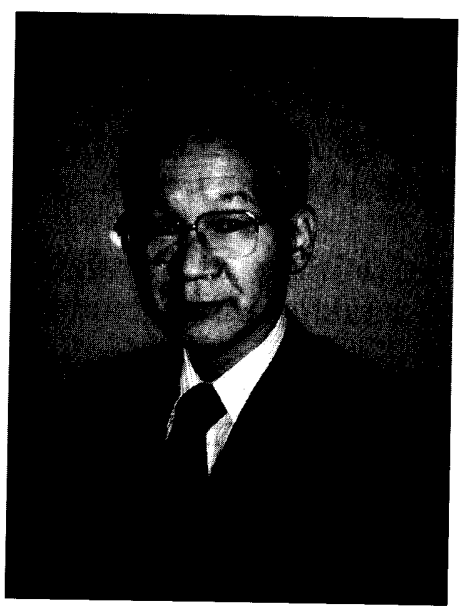

一方，私たち脳神経外科では，脊㖪脊椎分野における基 礎的研究が残念ながら非常にそしいという現実がありま す. 恐らくはわが国の整形外科医達が行っている研究の 5 分の 1 か, 10 分の 1 程度のものしか脳神経外科医によ ってなされていないのが現実だと思います，基礎的研究 の裏付けが無く，単なる技術のみを競うようでは私たち の脊䯣外科にはあまり素晴らしい未来は無いと思いま す．手術に関する限り，第一線の病院で行えないものは ありませんが，こと基礎的研究に関しては残念ながら現 状では市中病院や私的病院では行えません，各大学，少 なくとも leading universityと呼ばれる大学の指導的な 先生方には，この面での一層の奮起を願う次第です。ま た脊髄脊椎外科を志す若い人々においては，臨床の腕に 磨きをかけることは当然のことであり，少なくとも数年 間はこの分野の基礎的研究に従事して学問の嵩上げに努 めて頂きたいと切に願っています。

これからのわが国の脳神経外科に扔ける脊髄脊椎外科 の発展を心から願っています。

\section{藤枝平成記念病院脊髄脊椎疾患治療センター} 花北順哉 